\title{
Bowel rehabilitation of individuals with spinal cord injury: video production
}

\author{
Reabilitação intestinal de indivíduos com lesão medular: produção de vídeo \\ Rehabilitación intestinal de individuos con lesión medular: producción de vídeo
}

\section{Laura Terenciani Campoy', Soraia Assad Nasbine Rabeh', Fabiana Faleiros Santana Castro', Paula Cristina Nogueira', César Augusto Sangaletti Terçariol"}

' Universidade de São Paulo, Ribeirão Preto College of Nursing. Ribeirão Preto, São Paulo, Brazil.

"Universidade Barão de Mauá de Ribeirão. Ribeirão Preto, São Paulo, Brazil.

How to cite this article:

Campoy LT, Rabeh SAN, Castro FFS, Nogueira PC, Terçariol CAS. Bowel rehabilitation of individuals with spinal cord injury: video production. Rev Bras Enferm [Internet]. 2018;71(5):2376-82. DOI: http://dx.doi.org/10.1590/0034-7167-2017-0283

Submission: 06-05-2017 Approval: 10-07-2017

\section{ABSTRACT}

Objective: produce and validate an educational video about bowel emptying maneuvers for training of individuals with neurogenic bowel in bowel rehabilitation process. Method: this is a methodological study developed in four stages: script/storyboard production, validation, educational video production and pilot study, which was conducted from January 2013 to July 2015. Instruments for validation, which was performed from December 2014 to February 2015 by a group of experts. A value equal to or greater than $70 \%$ was considered for validation of agreement and relevance of the script and storyboard, using descriptive statistics for data analysis. Results: the script and storyboard were validated by $94 \%$ of the experts in the subject and $100 \%$ of the technicians. After validation and video recording, the pilot study was conducted with six individuals with neurogenic bowel $-100 \%$ of them evaluated the video positively. Conclusion: the video may contribute to the education of individuals with neurogenic bowel.

Descriptors: Spinal Cord Injuries; Rehabilitation; Neurogenic Bowel; Nursing; Video-Audio Media.

\section{RESUMO}

Objetivo: produzir e validar vídeo educativo sobre manobras de esvaziamento intestinal para capacitação de indivíduos com intestino neurogênico, no processo de reabilitação intestinal. Método: estudo metodológico, desenvolvido em quatro etapas: produção do roteiro/storyboard, validação, produção do vídeo educativo e estudo-piloto. Ocorreu no período de janeiro de 2013 a julho de 2015. Para a validação, utilizaram-se instrumentos, sendo realizada por um comitê de especialistas, no período de dezembro de 2014 a fevereiro de 2015. Considerou-se valor igual ou superior a 70\% para validação de concordância e pertinência do roteiro e storyboard, utilizando-se estatística descritiva para análise dos dados. Resultados: o roteiro e storyboard foram validados por $94 \%$ dos especialistas na temática e $100 \%$ dos especialistas técnicos. Após validação e gravação do vídeo, foi realizado estudo-piloto com seis indivíduos com intestino neurogênico, dos quais $100 \%$ avaliaram o vídeo positivamente. Conclusão: o vídeo poderá contribuir para a educação de indivíduos com intestino neurogênico.

Descritores: Traumatismos da Medula Espinhal; Reabilitação; Intestino Neurogênico; Enfermagem; Mídia Audiovisual.

\section{RESUMEN}

Objetivo: Producir y validar video educativo sobre maniobras de vaciamiento intestinal para capacitar individuos con intestino neurogénico sobre el proceso de rehabilitación intestinal. Método: Estudio metodológico desarrollado en cuatro etapas: guionado/storyboard, validación, producción del vídeo educativo y prueba piloto. Realizado entre enero 2013 y julio2015. Validación mediante instrumentos, efectuada por comité de expertos, con experiencia en vídeos de diciembre 2014 a febrero 2015. Valor de concordancia y pertinencia de guionado y storyboard considerado en $70 \%$ o superior. Datos analizados por estadística descriptiva. Resultados: Guionado y storyboard validados por $94 \%$ de expertos en temática y $100 \%$ de expertos técnicos. Validado y grabado el vídeo, se realizó prueba piloto con seis individuos con intestino neurogénico, 100\% evaluó positivamente el vídeo. Conclusión: El vídeo contribuirá a educar a individuos con intestino neurogénico.

Descriptores: Traumatismos de la Médula Espinal; Rehabilitación; Intestino Neurogénico; Enfermería; Medios Audiovisuales. 


\section{INTRODUCTION}

Diseases and injuries of the central nervous system (CNS), and their consequent sequelae, have become more prevalent in contemporary society due to population aging, increased violence and resulting traumatic injuries; however, improved care during the acute phase of the diseases has increased the survival of individuals affected by spinal cord injuries ${ }^{(1)}$. National and international studies show a higher incidence of spinal cord injuries $(\mathrm{SCl})$ between the second and third decades of life, predominantly in male patients, economically and sexually active, mainly due to car accidents (collision and rollover), followed by falls and violence (gunshot) ${ }^{(2-5)}$.

The complications resulting from $\mathrm{SCl}$ include neurogenic bowel dysfunction, which is defined as a colon disorder due to lack of central nervous control. Individuals with neurogenic bowel may alternate between constipation and fecal incontinence before receiving bowel regulation training. Such occurrence causes physical and psychological problems to these individuals ${ }^{(6-7)}$.

To address bowel problems of individuals with $\mathrm{SCl}$, international guidelines were developed by the Consortium for Spinal Cord Medicine $(\mathrm{CSCM})^{(8)}$ and translated into Portuguese ${ }^{(9)}$, with a focus on the prevention and treatment of complications, in which nurses have a special role in evaluating the signs and symptoms presented by the individuals and proposing a care plan, involving family members and caregivers in care dynamics.

Individuals with $\mathrm{SCl}$ should be inserted into a bowel rehabilitation program to recover the standard bowel functioning, ensure bowel emptying frequency of at least three times a week, and recover the evacuation control, performing bowel emptying maneuvers at regular times to reduce incontinence and prevent complications resulting from fecal impaction. Consequently, bowel rehabilitation will result in improved quality of life and participation in society ${ }^{(6-7,10-11)}$.

Health professionals working in bowel rehabilitation should focus on health education and preparation of individuals with $\mathrm{SCl}$ and their family members, to promote safety and quality of care provided. For the continuity of care, especially at home, it is critical to prepare the individual/family in order to promote self-care ${ }^{(3,5)}$.

Care should be provided by a multidisciplinary team based on interdisciplinary practice, developing actions focused on individuality, autonomy, and bonding, seeking comprehensive care and improving the quality of life of these individuals ${ }^{(10)}$.

In nursing, we have invested in the production of virtual educational tools for teaching and care practice, which are known as hypermedia. Such tools are the result of a combination of several media resources (text, picture, animation, video, among others), which are easily posted on the internet, and, currently, they are an important resource in education. In this context, the literature has successful experiences in the production of educational videos for the health field. These studies show positive results after the adoption of videos, with improved knowledge of the target audience ${ }^{(12-16)}$.

Studies conducted in Brazil with $\mathrm{SCl}$ patients to identify knowledge about bowel complications, self-care practices and guidance received during the hospitalization period related to post-injury bowel functioning showed knowledge gaps particularly regarding the preparation of these patients for bowel problem management ${ }^{(3,5,17)}$.

Considering the need for teaching self-care procedures in bowel rehabilitation to individuals with neurogenic bowel, the development of current and attractive teaching methods, such as educational videos, is proposed as a strategy that may favor learning for the management of the neurogenic bowel.

\section{OBJECTIVE}

To produce and validate an educational video on bowel emptying maneuvers for training to patients with neurogenic bowel in bowel rehabilitation process.

\section{METHOD}

\section{Ethical aspects}

The study project was approved by the Research Ethics Committee of the Ribeirão Preto College of Nursing at University of São Paulo, according to Resolution 466/12, Letter 300/2013.

\section{Study design}

This is a methodological study.

\section{Methodology procedures}

The stages illustrated in the flowchart below were followed for video production.

\begin{tabular}{|l|l|}
\hline Stage 1 & $\begin{array}{l}\text { - Script/storyboard production } \\
\text { - Data collection instrument production }\end{array}$ \\
\hline Stage 2 & - Script/storyboard validation \\
\hline Stage 3 & $\bullet$ Educational video production \\
\hline Stage 4 & $\bullet$ Pilot study \\
\hline
\end{tabular}

Figure 1 - Stages of study development, Ribeirão Preto, São Paulo, Brazil, 2017

For script and storyboard production, the recommendations of the Intestino Neurogênico: Guia para Pessoas com Lesão Medular ${ }^{(9)}$ (Neurogenic Bowel Guide for People with Spinal Cord Injury) were observed.

The script addresses the video content and it is made up of seven units.

Unit I: introduction - shows information about the educational video, such as video title, authors/people involved, production site, target audience, objectives, estimated duration and characters.

Unit II: nurse examination - a nurse interview was prepared to simulate a fictitious clinical case, in which a patient had $\mathrm{SCl}$ with consequent paraplegia, neurogenic bowel and nursing diagnosis of constipation. Horizontal interaction occurred between the two characters in the setting, who played the roles of nurse and patient; the main author of the study played the nurse role.

Unit III: essential knowledge for understanding the problem - in this unit, the nurse presented the concepts of $\mathrm{SCl}$ and its implications for the patient, with emphasis on complications 
related to bowel dysfunction, such as reflexic and areflexic neurogenic bowel.

Unit IV: care plan/bowel rehabilitation program - it presented the nursing care planning, addressing general aspects of the bowel rehabilitation program.

Unit V: nursing intervention/bowel emptying maneuvers presentation of maneuvers such as training on how to use the toilet, abdominal massage, Valsalva maneuver, abdominal press, digital rectal touches and manual stool removal.

Unit VI: other measures to help bowel control and the benefits of the patient's active participation in the bowel rehabilitation program.

Unit VII: references and credits to collaborators - it presented bibliographical references and credits to collaborators to script, storyboard and video production.

After the script production, the storyboard was developed. The storyboard content was the same as for the script, following the same division. The storyboard acts as an organizer, detailing the scenes for video preview, and it consisted of three columns. The first, audio/narration, had all the script content; the second, images/scenes, showed the description of scenes and the places where the video was recorded; and the last column had the description of photos/animations used in the video. This way, the experts were able to preview the video and perform evaluations.

Pasquali's model (2011) ${ }^{(18)}$ was used for script and storyboard validation, as well as instruments based on similar studies but adapted to the theme in question ${ }^{(12,15-16,19)}$. For content validation, an instrument was used containing 15 questions related to the items: objective, content, relevance, and environment (and a field for suggestions) and, for technical validation, another instrument was used with 11 questions regarding the items: functionality, usability and efficiency (and a field for suggestions). The questions were analyzed in terms of levels of agreement and relevance.

\section{Participants}

A group of experts was created for the validation study; it consisted of ten nurses, all of them with experience in providing care to individuals with neurogenic bowel, and three communication experts with video production experience, who were selected by convenience. The selection of experts was also based on other studies of the same nature ${ }^{(12,15-16,19)}$, in which experts in content and technicians were selected, with professional experience and production on the subject.

\section{Study setting}

The video storyboard and script were validated when they reached at least $70 \%$ of "strongly agree" and/or "agree" answers for each item of the instrument. This criterion was described in studies for the validation of virtual learning environments ${ }^{(13-14,16)}$. The suggestions were analyzed and adopted when relevant.

\section{Data collection and organization}

Data collection for script and storyboard validation was performed from December 2014 to February 2015.

\section{Video production}

After script and storyboard validation, the educational video was produced. The video was recorded in the simulation center of a nursing school in the State of São Paulo, which has low- and medium-fidelity simulation laboratories, after an authorization from the board of directors, and at the studio of the Computer Center of Universidade de São Paulo (USP). The characters signed an informed consent form, authorizing the use of their image in the video. Photos, pictures and animation, and video recording and editing were conducted by an audiovisual operator of the institution's Multimedia Creation and Production Service.

For semantic evaluation ${ }^{(18)}$, a pilot study was conducted at a rehabilitation center with a convenience sample of six individuals with spinal cord injury and neurogenic bowel, in rehabilitation follow-up, to evaluate video clarity, understanding, and duration. This step was performed after presenting the edited video to the individuals who then answered an instrument, the same used with the experts, but adapted to the target audience. It contained 11 questions of sociodemographic and clinical characterization, and five questions related to the video content, images, and scenes.

\section{Data analysis}

The Statistical Package for the Social Sciences ${ }^{\circledR}$ (SPSS), version 21.0, was used in data compilation and analysis. For the descriptive statistical analysis of data, absolute and relative frequencies were calculated for qualitative variables, as well as mean and median values and minimum, maximum and standard deviation for quantitative variables.

\section{RESULTS}

\section{Script/storyboard validation}

The group of experts had 13 members. Among the ten content experts, all were female, aged 30 to 58 years, mean of 37.6 years $( \pm 7.52)$. Regarding their current professional activity, six $(60 \%)$ were from the rehabilitation area, three $(30 \%)$ were nursing professors and one was from the area of epidemiological surveillance, with prior experience in rehabilitation. Length of service varied from six months to 15 years, mean of eight years $( \pm 4.55)$. All participants had stricto sensu or lato sensu graduate degrees, with a predominance of master's and doctor's degrees as the highest educational level.

In content validation, all experts agreed that the video objectives were consistent with the clinical practice. In the 'content' item, suggestions were made regarding changes to terms and addition of more learning objects, because, according to the experts, the script/storyboard had highly technical language, which could make it difficult for the target audience to understand. The suggestions were analyzed and adopted, with the adaptation of terms and inclusion of more photos, pictures, and animation.

One of the suggestions proposed to separate the maneuvers by type of bowel - reflexic and areflexic, which was relevant, since individual evaluation in the beginning of the bowel rehabilitation program is required to identify the sensitivity and preservation of the structures to design the care plan. After addressing these aspects, the group decided to demonstrate bowel emptying maneuvers for both types of bowels and both complete and incomplete injuries. 
In the evaluation of the relevance of images and scenes for the practice of maneuvers, one of the suggestions proposed to demonstrate the suppository administration. The group decided to demonstrate it in the video only with conservative maneuvers without the use of stimulant medications, because they should be used only when necessary, and not continuously, such as bowel emptying maneuvers.

Regarding the 'environment' item, the experts were unanimous, due to the adequacy of the simulated setting for video production for the teaching-learning process. In the evaluation from content specialists, the agreement of the answers regarding the instrument items was $94 \%$.

Another relevant suggestion was to present the clinical case by the characters themselves (nurse and patient) during the nurse examination, in which both would interact through horizontal dialogue. This suggestion was accepted and the case was reformulated according to the dialogical strategy; then, the nurse started to collect data from the patient's report about her case, her experiences, needs, challenges, doubts and practices, regarding bowel functioning. Chart 1 shows the pre-validation script of unit II and post-validation script, after incorporating the suggested changes.

Of the three technicians, two were male, aged 37 to 45 , and worked as analysts in digital media and educational technologies, multimedia production and information systems, with more than ten years of experience. Regarding the highest academic qualification, two had specialization in distance education, systems analysis and video production, and one was a doctor in nursing.

The technicians evaluated the items of functionality, usability, and efficiency, based on the script and storyboard, with 100\% agreement of the answers, as well as relevant suggestions that were adopted.

In the questions about usability, suggestions were made regarding the selection of visual (illustration/animation) and audio resources (voice recording/soundtrack), as well as editing/finish to attract the interest and attention of patients. In the item about efficiency, the estimated time of 15 minutes in relation to the number of scenes and communication between the characters was considered adequate.
The video script and storyboard obtained more than $70 \%$ agreement of the content experts and technicians, so they were considered as validated. After that, the stage of video production took place.

\section{Video production}

Based on the suggestions made by the experts, the nurse examination was reformulated with the adoption of the dialogical strategy between the nurse and the patient. The study setting simulated an outpatient rehabilitation service for video recording, which took place at the nursing practice simulation center of a higher education nursing institution.

Three settings were used in video recording: Laboratory II, Primary Care Laboratory (simulated house) and a studio. Rehearsal and recording of scenes took nine hours (four days) in April 2015.

Setting 1: nurse examination/bowel emptying maneuvers - the following materials were used to record nurse examination and demonstration of maneuvers (abdominal massage, digital rectal touches, and manual stool removal): anatomical piece of the vertebral column, pelvis model, wheelchair, hospital bed with white sheet, white face and bath towels, liquid soap, moisturizing cream and oil, medical gloves, water-soluble lubricant, and brown modeling dough. Laboratory II presented good lighting and large physical space, which facilitated the video recording. The time spent was one hour to prepare the setting and another three hours of video recording, totaling four hours.

Setting 2: simulated house/training for bowel emptying maneuvers - aspects related to bowel retraining and training of maneuvers in the home environment were addressed in this laboratory. It had four rooms: kitchen, living room, bathroom, and bedroom. When recording the following maneuvers: using the toilet, abdominal massage, Valsalva maneuver and abdominal press, the patient (character) used a wheelchair and a shower chair to demonstrate the maneuvers performed in the bathroom of the house, illustrated in Figure 1. The recording time was one hour.

Chart 1 - Pre- and post-validation versions of the script of unit II: nurse examination, Ribeirão Preto, São Paulo, Brazil, 2017

\section{PRE-VALIDATION VERSION}

A.S., 26 years old, female, white, single, nursing student, had a car accident 6 months ago, and a spinal cord injury at the lumbar level (L2), she lives with her mother, her caregiver. She came to the health service complaining of malaise, abdominal discomfort, bowel incontinence, anal bleeding and no bowel elimination for 10 days. At her physical examination: distended abdomen, decreased airflow sounds, at palpation, presence of fecal impaction. She does not attend any rehabilitation center. She received guidance on bowel complications associated with $\mathrm{SCl}$ at discharge from the first post-injury hospitalization. She uses oral laxatives daily and does not perform bowel emptying maneuvers. She says she has a low-fiber diet, takes small amounts of liquid daily and that she has presented difficult bowel elimination after she had the car accident; she reports daily evacuation before the accident.

\section{POST-VALIDATION VERSION}

Hi Ana, I'm Laura, I'm a nurse here at this rehabilitation service and I'd like to know a little about your case. (Nurse)

Hi Laura, I'm 26 years old, single, a student, I live with my mother, who is my caregiver. Six months ago I had a car accident and was informed that I had a spinal cord injury at the lumbar level at L2. I came to this service because I felt malaise, abdominal discomfort and I haven't evacuated for 10 days. (Patient)

Do you attend any rehabilitation service, Ana? (Nurse)

No, I don't. (Patient)

Have you received any guidance regarding bowel complications at discharge when you were hospitalized? (Nurse)

Yes, when I was discharged at the first hospitalization, they told me that I would have some bowel complications because of the accident. (Patient)

Do you use any medication for bowel elimination? (Nurse)

Yes. After the accident, I started taking oral laxatives daily, something I didn't use to do, because before the accident I had no problem evacuating, I used to do it every day at the same time, after the meal. (Patient) 


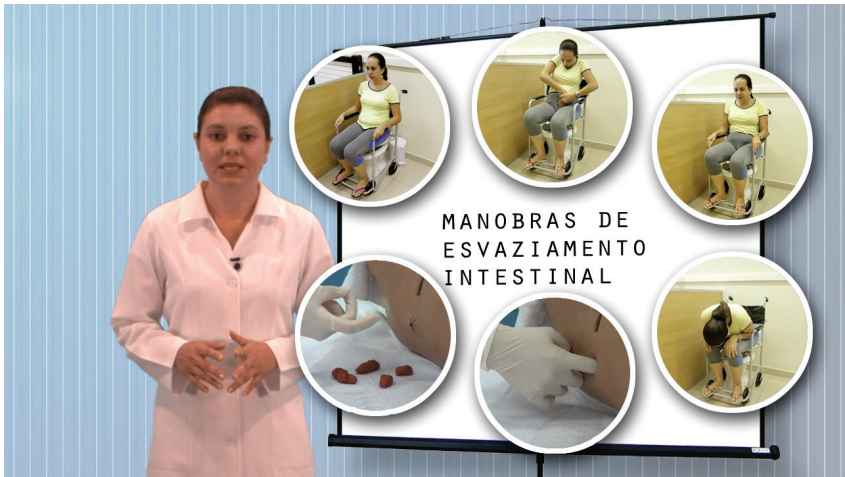

Figure 2 - Representation of setting 2, related to the simulated house and training on bowel emptying maneuvers, Ribeirão Preto, São Paulo, Brazil, 2017

Setting 3: studio at CIRP-USP - the studio was equipped with artificial LED and incandescent lamps, acoustic insulation and infinite background, lavalier microphone, Sony HXR $\mathrm{NX} 5{ }^{\circledR}$ camera, Manfrotto ${ }^{\circledR}$ tripod, and LG 21" monitor. Voice recording was performed in this studio by the nurse (character), and the recording time was two hours.

The characters had a prior rehearsal to estimate material resources, preparation of the characters and recording time. A photo essay was performed of the scenes and materials that would be used. All materials had hidden labels; however, they were identified by tags. The time spent was two hours.

Several professionals collaborated to video recordings, including technicians in multimedia, digital media and educational technologies, the study advisor and the nurse in charge of the laboratories with experience in video production.

The pre-validation version of the storyboard contained 57 scenes, and the post-validation version, 67 scenes. The scenes were repeated several times for better picture and audio.

The photos and video were produced using a Canon EOS $7^{\circledR}$ digital camera, and Adobe Flash and Photoshop ${ }^{\circledR}$, Adobe Photoshop and Audacity ${ }^{\circledR}$ and Adobe Premiere ${ }^{\circledR}$ were used in animation, image/sound treatment and video editing. The edited video was in HD 1280x720 format and its duration was 13 minutes and 43 seconds. The process in question was supported by the Multimedia Creation and Production Service of the nursing higher education institution, and it was conducted by the audiovisual operator of the service between April and June 2015.

The pilot study had the participation of six individuals with $\mathrm{SCl}$ and diagnosis of neurogenic bowel. Of these individuals, five (83.3\%) were male and four (66.6\%) had completed high school. Regarding their participation in bowel rehabilitation programs and bowel emptying maneuvers, four $(66.6 \%)$ reported current or prior participation, and four $(66.6 \%)$ were already performing the maneuvers.

In the semantic validation, $100 \%$ of the individuals evaluated the video positively in terms of comprehension, clarity and time, highlighting the important guidance contained in the video.

\section{DISCUSSION}

Currently, with information and communication technologies (ICT), health education can be conducted in an easier and more accessible way. ICTs can make the teaching-learning process easier through the use of active methods and offer individuals greater access to sources of knowledge, without geographical limits ${ }^{(20)}$.

Among the ICTs, video, which originates from the Latin word video (I see), refers to a technology for the education of electronic analog or digital signals, which represents images in motion, thus facilitating the learning process of viewers, as it is attractive and draws attention. Also, video refers to the recording of moving images and animation comprised of sequential photos, which result in animated images ${ }^{(12,16)}$.

The video produced in this study was for individuals with neurogenic bowel, considering the clinical characteristics of the types of bowel, to offer tools for such individuals to perform bowel actions with safety. The video production was based on assumptions of health education and dialogicity, problematization and reflection of Paulo Freire ${ }^{(21)}$, in order to improve the preparation of these individuals through educational intervention to help them achieve autonomy and greater independence.

To ensure video quality, content and technique were validated by a group of experts, who evaluated the video in terms of clarity and representativeness of script and storyboard scenes, according to the intended thematic unit, easy understanding by the target audience, form of presentation and coverage, including conceptual elements of scene relevance ${ }^{(22)}$.

The profile of content experts, experienced in the theme, contributed to script and storyboard validation and improvement with the suggestions made. This process led to the video produced for this study, with quality subsequently attested by individuals with neurogenic bowel. This strategy was also used by other authors ${ }^{(16,23)}$ for the construction of audiovisual media.

From the suggestions of content experts, language was the main aspect highlighted as it emphasized the importance of a more informal and less technical language for easy understanding of the target audience. In the technical validation, the suggestions regarding video editing and selection of audiovisual resources were relevant, attracting the interest and attention of individuals. They were also unanimous on video duration - it should not exceed 15 minutes.

Studies involving the production of educational videos report a recommended duration. The final version of the video produced in this study lasted 13 minutes and 43 seconds. Researchers ${ }^{(24)}$ have quoted in their studies that this type of digital object should not exceed 15 minutes to keep the viewer's attention.

The video production in the context of nurse examination favored the approach to the problem and teaching of bowel emptying maneuvers. Nurses have a preponderant role in preparing individuals for bowel rehabilitation. Studies on this theme have shown nurses have to use instruments when performing this role and the nursing interventions recommended in the literature ${ }^{(7,11)}$.

Another very relevant suggestion referred to the presentation of a simulated clinical case during the nurse examination to favor the dialogue between the characters. This change made the video more dialogic, allowing a greater participation of the patient and placing a greater value on the dialogue between the characters. The communication between the characters changed from vertical to horizontal interaction, and became dialogic and reciprocal, in agreement with the education/care process. 
Dialogic communication, in the context of health education in nursing, in agreement with a transformative discourse, takes place through active, critical and questioning participation of the patient. This educational practice contradicts the vertical model, in which there is no exchange of information, knowledge and experience ${ }^{(21)}$.

In problem-solving education, the presentation of the problem to be studied should be approached from a real scenario, with situations that arise from the daily life of the individuals in question ${ }^{(21)}$. For scenario replication, the simulation strategy was used in video production. Materials and equipment used in this study were identical to those of clinical practice, favoring the reproduction of the setting, which was close to reality.

A randomized study, conducted at the University of Turin, Italy, analyzed the efficacy of a video for decubitus change of individuals on bed and compared the performance of two groups of nursing undergraduates, one group watched the video and the other group received the information in writing, it was demonstrated; the results of this study showed that the video group performed the procedure more effectively and presented a better performance. Therefore, the video was considered as an important tool to reinforce previous learning ${ }^{(25)}$.

Titler ${ }^{(22)}$ points out the relevance of using study results and evidence-based innovations in clinical practice to generate more effective, safer and quality care. It also emphasizes, among the diversity of strategies to be implemented, the practical aspect of incorporating innovations, the attempt to change a certain condition with the support of multidisciplinary teams. In this sense, the intention with the educational video produced in this study is that it should help SCl patients to fulfill their bowel needs, since it was positively evaluated by $100 \%$ of the pilot study participants.

In general, the changes made during the video production were in compliance with the validation process of the content and reference adopted and, therefore, the video can help individuals with neurogenic bowel. In addition, it is committed to disseminating the content on the subject, with the video available in different media for easy dissemination and access.

\section{Study limitations}

This study was conducted under a master's degree project in a period of 30 months and the time spent for the video production process, including the four stages, did not allow a pilot study with a larger number of participants. More robust validation studies will be required to test its effectiveness.

\section{Contributions to nursing}

This study intends to contribute to quality care, promoting the effectiveness and efficiency of nursing activities regarding the rehabilitation of individuals with neurogenic bowel, for self-care and management of this chronic condition.

The video produced in this study may contribute to nursing care improvement, focused on the rehabilitation of individuals with neurogenic bowel and their caregivers, besides being a technological tool that can be used in virtual and face-to-face learning environments.

\section{CONCLUSION}

The process of producing an educational video required time, specific knowledge about the theme, collaboration, and experiences of researchers and experts in the field, resulting in a current educational material with a potential for innovation in nursing care in terms of bowel rehabilitation of individuals with neurogenic bowel.

Considering the proposed objectives, this study concludes the educational video has been validated. It will be published in institutional repositories (http://eaulas.usp.br/portal/video. action?idltem $=8104$ ) and on a video sharing website of open access. The video should be used in the context of bowel rehabilitation and, in case of doubts after watching it, these should be discussed with health professionals with expertise in the subject.

\section{FUNDING}

This study was conducted under a master's degree project funded by the São Paulo Research Foundation (FAPESP), process no. 2013/16334-5.

\section{REFERENCES}

1. National Spinal Cord Injury Statistical Center. Spinal cord injury facts and figures at a glance. J Spinal Cord Med[Internet]. 2014[cited 2016 Sep 23];37(1):117-8. Available from: https:/www.ncbi.nlm.nih.gov/pmc/articles/PMC4066546/

2. França IS, Coura AS, Sousa FS, Almeida PC, Pagliuca LM. Quality of life in patients with spinal cord injury. Rev Gaúcha Enferm[Internet]. 2013[cited 2016 Sep 23];34(1):155-63. Available from: http://www.pubpdf.com/pub/23781737/ Quality-of-life-in-patients-with-spinal-cord-injury

3. Rabeh SAN, Caliri MHL. Functional ability in individuals with spinal cord injury. Acta Paul Enferm [Internet]. $2010[$ cited 2016 May 21];23(3):321-7. Available from: http://www.scielo.br/pdf/ape/v23n3/en_v23n3a02.pdf

4. Brasil. Ministério da Saúde. Secretaria de Atenção à Saúde. Departamento de Atenção Básica. Política Nacional de Atenção Básica. Brasília: Ministério da Saúde; 2012. (Série E, Legislação em Saúde).

5. Campoy LT, Rabeh SAN, Nogueira PC, Vianna PC, Miyazaki MY. Práticas de autocuidado para funcionamento intestinal em um grupo de pacientes com trauma raquimedular. Acta Fisiatr [Internet]. 2012 [cited 2016 May 21];19(4):228-32. Available from: http://www.actafisiatrica.org.br/detalhe_artigo.asp?id = 482

6. Krassioukov A, Eng JJ, Claxton G, Sakakibara BM, Shum S, SCIRE Research Team. Neurogenic bowel management after spinal 
cord injury: a systematic review of the evidence. Spinal Cord [Internet]. 2010 [cited 2016 May 21];48(10):718-33. Available from: https://www.ncbi.nlm.nih.gov/pmc/articles/PMC3118252/

7. Rabeh SAN, Nogueira PC, Caliri MHL. Funcionamento intestinal e a relação com a independência funcional de indivíduos com lesão medular. Columna [Internet]. 2013 [cited 2016 May 21];12(2):153-6. Available from: http://www.scielo.br/pdf/coluna/v12n2/13.pdf

8. Consortium For Spinal Cord Medicine-CSCM. Neurologic bowel: what you know: a guide for people with spinal cord injury. Washington: Paralysed Veterans of America; 1999b.

9. Caliri MHL, Furlan MLS, Defino HLA. Tratamento do intestino neurogênico em adultos com lesão da medula espinhal. Diretrizes para uma prática baseada em evidências. Columna [Internet]. 2005 [cited 2016 May 21];4(2):102-5. Available from: http://static. revistacoluna.com/pdf/volume4/vol_4_[2]_pag_102_105_2005.pdf

10. Brasil. Ministério da Saúde. Secretaria de Atenção à Saúde. Departamento de Ações Programáticas Estratégicas e Departamento de Atenção Especializada. Diretrizes de Atenção à Pessoa com Lesão Medular. Brasília: Ministério da Saúde; 2015.

11. Faleiros F, Paula EDR. Constipation in patients with quadriplegic cerebral palsy: intestinal reeducation using massage and a laxative diet. Rev Esc Enferm USP [Internet]. 2013 [cited 2016 May 21];47(4):836-42. Available from: http://www.scielo.br/pdf/reeusp/ v47n4/en_0080-6234-reeusp-47-4-0836.pdf

12. Barbosa RM, Bezerra AK. Validation of an educational video for the promotion of attachment between seropositive HIV mother and her child. Rev Bras Enferm [Internet]. 2011 [cited 2016 May 21];64(2):328-34. Available from: http://www.scielo.br/pdf/reben/ v64n2/a17v64n2.pdf Portuguese

13. Góes FSN, Fonseca LMM, Furtado MCC, Leite AM, Scochi CGS. Evaluation of the virtual learning object "Diagnostic reasoning in nursing applied to preterm newborns". Rev Latino-Am Enfermagem[Internet]. 2011 [cited 2016 May 21];19(4):894-901. Available from: http://www.scielo.br/pdf/rlae/v19n4/pt_07.pdf

14. Ferecini GM. Desenvolvimento e avaliação do objeto digital de aprendizagem sobre o aleitamento materno do prematuro[Tese]. Ribeirão Preto, SP: Escola de Enfermagem de Ribeirão Preto da Universidade de São Paulo; 2012. 159 p.

15. Freitas LV, Teles LMR, Lima TM, Vieira NFC, Barbosa RCM, Pinheiro AKB, et al. Physical examination during prenatal care: construction and validation of educational hypermedia for nursing. Acta Paul Enferm [Internet]. 2012 [cited 2016 Dec 7];25(4):5818. Available from: http://www.scielo.br/pdf/ape/v25n4/en_16.pdf

16. Ferreira MVF, Godoy S, Góes FSN, Rossini FP, Andrade D. Câmera e ação na execução do curativo do cateter venoso central. Rev Latino-Am Enfermagem [Internet]. 2015 [cited 2016 May 21];23(6):1181-6. Available from: http://www.revistas.usp.br/rlae/ article/view/108034

17. Furlan MLS, Caliri MHL, Defino HL. Intestino neurogênico: guia prático para pessoas com lesão medular, Parte I. Columna[Internet]. 2005[cited 2016 Dec 2];4(3):113-68. Available from: http://static.revistacoluna.com/pdf/volume4/vol_04_03_151-157_2005.pdf

18. Pasquali L. Psicometria: teoria dos testes na psicologia e na educação. 4ed. Petrópolis, RJ: Vozes, 2011.

19. Morais MLC. Construção e validação de hipermídia educacional em saúde sexual: abordagem à consulta de enfermagem ginecológica. [Dissertação]. Fortaleza, CE: Universidade Federal do Ceará; 2011. 108 p.

20. Mendes IAC, Seixas CA. E-learning e Educação a Distância: guia prático para implantação e uso de sistemas abertos. Ribeirão Preto: Editora Atlas, 2006. 151p.

21. Freire P. Pedagogia do oprimido. 29a ed. São Paulo: Paz e Terra, 2000.

22. Titler MG. The evidence for evidence-based practice implementation. In: Patient Safety and Quality an Evidence-Based Handbook for Nurses. Rockville, MD: Agency for Healthcare Research and Quality, US; 2008.

23. Cucick CD. Desenvolvimento de um vídeo educativo para a aprendizagem do autocateterismo vesical intermitente. [Dissertação]. Ribeirão Preto, SP: Escola de Enfermagem de Ribeirão Preto da Universidade de São Paulo; 2016. 154 p.

24. Hartsell T, Yuen S. Video streaming in online learning. AACE J [Internet]. 2006 [cited 2016 May 21];14(1):31-43. Available from: http://www.learntechlib.org/p/6152

25. Salina SL, Ruffinengo C, Garrino L, Massariello P, Charrier L, Martin B, et al. Effectiveness of an educational video as an instrument to refresh and reinforce the learning of a nursing technique: a randomized controlled trial. Perspect Med Educ [Internet]. 2012 [cited 2016 May 21];1(2):67-75. Available from: https://www.ncbi.nlm.nih.gov/pmc/articles/PMC3540345/ 